\title{
KEGIATAN PENDUKUNG BK
}

\author{
Oleh : \\ FEBRI KURNIA (19035084) \\ PRODI PENDIDIKAN KIMIA \\ UNIVERSITAS NEGERI PADANG \\ INDONESIA
}

\begin{abstract}
Abstrak
Kegiatan pendukung bimbingan dan konseling meliputi kegiatan pokok aplikasi instrument bimbingan dan konseling, himpunan data, kunjungan rumah, konferensi kasus, tampilan kepustakaan, dan alih tangan kasus. Semua jenis kegiatan pendukung dilaksanakan secara langsung, dikaitkan pada keempat bidang bimbingan, serta disesuaikan dengan karakteristik dan kebutuhan klien. Hasil kegiatan pendukung dipakai untuk memperkuat satu atau beberapa jenis layanan bimbingan dan konseling.Pokok masalah yang diajukan dalam paper ini yaitu mengenai kegiatan pendukung BK diamana bertujuan untuk mengetahui dan memahami kegiatan apa saja yang menjadi pendukung dalam proses bimbingan dan konseling
\end{abstract}

Keyword : aplikasi instrumentak BK,himpunana data,kunjungan rumah,konfrensi kasus, tampilan kepustakaan dan alih tangan kasus

\section{I.PENDAHULUAN}

\section{A.Latar Belakang}

Untuk mengembangkan potensi siswa dan membantu pemecahan masalah yang dihadapinya, perlu ada kegiatan layanan bimbingan dan konseling yang terorganisir, terprogram dan terarah. Tujuan umum bimbingan dan konseling adalah untuk membantu individu memperkembangkan diri secara optimal sesuai dengan tahap perkembangan dan predisposisi yang dimilikinya (seperti kemampuan dasar dan bakat-bakatnya), berbagai latar belakang yang ada (seperti latar belakang keluarga, pendidikan, status sosial ekonomi), serta sesuai dengan tuntutan positif lingkungannya.

Kegiatan pendukung pada umumnya tidak ditujukan secara langsung untuk memecahkan masalah klien, melainkan untuk memungkinkan diperolehnya data dan keterangan lian serta kemudahan - kemudahan atau komitmen yang akan membantu kelancaran dan keberhasilan kegiatan layanan terhadap klien. Kegiatan pendukung ini umumnya dilaksanakan tanpa kontak langsung dengan sasaran.

Kegiatan pendukung bimbingan dan konseling meliputi kegiatan aplikasi instrument bimbingan dan konseling, himpunan data, kunjungan rumah, konferensi kasus, tampilan kepustakaan, dan alih tangan kasus. Semua jenis kegiatan pendukung dilaksanakan secara langsung, dikaitkan pada keempat bidang bimbingan, serta disesuaikan dengan karakteristik dan kebutuhan klien. Hasil kegiatan pendukung dipakai untuk memperkuat satu atau beberapa jenis layanan bimbingan dan konseling

\section{B.Tujuan}


1. Menjelaskan aplikasi instrument bimbingan dan konseling

2. Menjelaskan himpunan data

3. Menjelaskan kunjungan rumah

4. Menjelaskan konferensi kasus

5. Menjelaskan tampilan kepustakaan

6. Menjelaskan alih tangan kasus

\section{II.METODE PENELITIAN}

Artikel ini disusun dengan metode dan langkah-langkah yang sistematis untuk memudahkan melakukan penelitian. Pada artikel ini, peneliti menggukan metode studi literatur dengan cara mengumpulkan literatur (bahan-bahan materi) yang bersumber dari buku, jurnal, dan sumber lainnya terkait ilmu tentang kegiatan pendukung bimbingan dan konseling

\section{III.KAJIAN TEORI DAN PEMBAHASAN}

Kegiatan pendukung bimbingan dan konseling meliputi kegiatan pokok aplikasi instrument bimbingan dan konseling, himpunan data, kunjungan rumah, konferensi kasus, tampilan kepustakaan, dan alih tangan kasus. Semua jenis kegiatan pendukung dilaksanakan secara langsung, dikaitkan pada keempat bidang bimbingan, serta disesuaikan dengan karakteristik dan kebutuhan klien. Hasil kegiatan pendukung dipakai untuk memperkuat satu atau beberapa jenis layanan bimbingan dan konseling (Prayitno, 2004).

\section{A. Aplikasi Instrumentasi BK}

Aplikasi instrumentasi bimbingan dan konseling merupakan kegiatan pendukung bimbingan dan konseling untuk mengumpulkan data dan keterangan tentang peserta didik, keterangan tentang lingkungan peserta didik, dan lingkungan yang lebih luas. Pengumpulan data ini dapat dilakukan dengan berbagai instrument, baik tes maupun non tes. Aplikasi instrumentasi adalah upaya pengungkapan melalui pengukuran dengan memakai alat ukur atau instrument tertentu. Hasil aplikasi ditafsirkan, disikapi dan digunakan untuk memberikan perlakuan terhadap peserta didik dalam bentuk layanan bimbingan dan konseling.

Fungsi utama bimbingan dan konseling yang diembankan oleh kegiatan penunjang aplikasi instrumentasi ialah fungsi pemahaman.

Materi umum aplikasi instrumentasi yaitu berupa data dan keterangan yang dikumpulkan melalui aplikasi instrumentasi pada umumnya, meliputi :

1. Kebiasaan dan sikap dalam beriman dan bertaqwa terhadap Tuhan Yang Maha Esa.

2. Kemampuan dan kondisi mental dan fisik peserta didik.

3. Kemampuan dan pengenalan lingkungan dan hubungan sosial.

4. Sikap, kebiasaan, keterampilan, dan kemampuan belajar.

5. Informasi karir dan pendidikan.

6. Kondisi keluarga dan lingkungan.

Ada beberapa pertimbangan yang perlu mendapat perhatian para konselor dalam penerapan aplikasi instrumentasi bimbingan dan konseling, antara lain :

1. Instrumentasi yang dipakai harus shahih dan terandalkan. 
2. Konselor bertanggungjabaw atas pemilihan instrument yang akan dipakai(tes atau non tes), monitoring pengadministrasiannya dan scoring, penginterpretasian skor dan penggunaan sebagai sumber informasi bagi pengambilan keputusan tertentu.

3. Pemakaian instrument harus disiapkan secara matang, bukan hanya persiapan instrument saja, tetapi persiapan instrument yang akan mengambil tes

4. Tes atau instrument apapun hanya salah satu sumber dalam rangka memahami individu (peserta didik) secara lebih luas dan mendalam.

5. Ada dan dipergunakannya instrument lainnya bukanlah syarat mutlak bagi pelaksanaan pelayanan bimbingan dan konseling.

\section{B. Himpunan Data}

Penyelenggaraan himpuanan data, yaitu kegiatan pendukung bimbingan dan konseling untung menghimpun seluruh data dan keterangan yang relevan dengan keperluan pengembangan peserta didik. Himpunan data perlu diselenggarakan secara berkelanjutan, sistematik, komprehensif, terpadu, dan sifatnya tertutup.Data yang terhimpun merupakan hasil dari upaya aplikasi instrumentasi, dan hasil dari himpunan data dimanfaatkan sebesar - besarnya dalam layanan bimbingan dan konseling.

Materi umum himpunan data yaitu :

1. Identitas peserta didik dan keluarga.

2. Hasil aplikasi instrumentasi.

3. Hasil belajar, karya tulis, dan rekaman kemampuan siswa.

4. Catatan anecdote .

5. Informasi pendidikan.

6. Laporan dan catatan khusus.

Fungsi utama bimbingan yang didukung oleh penyelenggaraan himpunan data adalah fungsi pemahaman. Keseluruhan data yang dikumpulkan itu dapat dikelompokkan menjadi :

1. Data pribadi (Cumulative Record), yaitu data yang menyangkut diri masing masing peserta didik secara perorangan. Himpunan data pribadi dilakukan terpisah untuk setiap peserta didik, karena himpunan data pribadi bersifat berkelanjutan, maka harus ada kerja sama antar guru kelas. Himpunan data pribadi peserta didik harus lengkap dan menyeluruh, tetapi harus tetap sederhana, ringkas, dan bersifat sepenuhnya.

2. Data kelompok, yaitu data yang menyangkut aspek tertentu dari sekelompok peserta didik, seperti gambaran menyeluruh hasil belajar peserta didik satu kelas, hasil sosiometri, laporan penyelenggaraan dan hasil diskusi atau belajar kelompok, penyelenggaraan dan isi bimbingan, dan konseling kelompok.

3. Data umum, yaitu data yang tidak secara langsung menyangkut diri peserta didik baik secara pribadi maupun kelompok. Data ini berasal dari luar diri peserta didik, seperti informasi pendidikan serta informasi lingkungan fisik, sosial dan budaya. Data ini biasanya dihimpun dalam bentuk tersendiri, contohnya bentuk buku, kumpulan tentang informasi pendidikan, dan informasi sosial budaya.

\section{Kunjungan Rumah}

Kunjungan rumah, yaitu kegiatan pendukung bimbingan dan konseling untuk memperoleh data, keterangan, kemudahan, dna komitmen bagi keterentaskannya 
permasalahan peserta didik melalui kunjungan ke rumahnya. Kegiatan ini memerlukan kerja sama yang penuh dari orang tua dan anggota keluarga lainnya. Penangan permasalahan peserta didik seringkali memerlukan pemahaman yang lebih jauh tentang suasana rumah atau keluarga peserta didik.

Tujuan utama kegiatan kunjungan rumah dan pemanggilan orang tua ke sekolah : 1. Memperoleh data tambahan tentang permasalahan peserta didik khususnya yang bersangkut - paut dengan keadaan rumah atau orang tua.

2. Menyampaikan kepada orang tua tentang permasalahan anaknya.

3. Membangun komitmen terhadap orang tua tentang penanganan masalah anaknya.

Materi umum kunjungan rumah :

1. Kondisi rumah tangga dan orang tua.

2. Fasilitas belajar yang ada di rumah.

3. Hubungan antara keluarga.

4. Sikap atau kebiasaan peserta didik di rumah.

5. Berbagai pendapat orang tua dan anggota keluarga inti lainnya terhadap peserta didik.

6. Komitmen orang tua dan anggota keluarga inti dalam perkembangan dan pengentasan masalah peserta didik.

\section{Konferensi Kasus}

Konferensi kasus, yaitu kegiatan pendukung bimbingan dan konseling untuk membahas permasalahan yang dialami oleh peserta didik dalam suatu forum pertemuan yang dihadiri oleh berbagai pihak yang diharapkan dapat memberikan bahan, keterangan kemudahan, dan komitmen bagi terentaskannya permasalahan tersebut. Pertemuan dalam rangka konferensi kasus bersifat terbatas dan tertutup.

Dalam konferensi kasus secara spesifik dibahas permasalahan ynag dialami oleh peserta didik tertentu dalam suatu forum diskusi yang dihadiri oleh pihak - pihak terkait yang diharapkan dapat memberikan data dan keterangan lebih lanjut serta kemudahan - kemudahan bagi terentasnya permasalahan tersebut. Pembahasan masalah dalam konferensi kasus juga menyangkut upaya pengentasan masalah dan peranan masing - masing pihak dalam upaya yang dimaksud. Dengan demikian, fungsi utama yang diemban oleh konferensi kasus adalah fungsi pemahaman dan pengentasan.

Tujuan konferensi kasus :

Saecara umum adalah untuk mencari interpretasi yang tepat dan tindakan - tindakan yang konkret yang dapat diambil. Dengan kata lain konferensi kasus bertujuan untuk mendapat gambaran yang lebih tepat mengenai diri kausu dengan maksud untuk memberikan pertolongan kepada kasus tersebut dalam memecahkan masalahnya. 1. Diperolehnya gambaran yang lebih jelas, mendalam, dan menyeluruh tentang permasalahan peserta didik. Gambaran yang diperoleh lengkap dan saling saling sangku - paut data atau keterangan yang satu dengan yang lainnya.

2. Terkomunikasinya sejumlah aspek permasalahan kepada pihak - pihak yang berkepentingan dan yang bersangkutan, sehingga penanganan masalah itu menjadi lebih mudah dan tuntas.

3. Terkoordinasinya penanganan masalah yang dimaksud sehingga upaya penanganan itu lebih efektif dan efisien. 


\section{E. Tampilan Kepustakaan}

Tampilan kepustakaan, yaitu kegiatan menyediakan berbagai bahan pustaka yang dapat digunakan peserta didik dalam pengembangan pribadi, kemampuan sosial, kegiatan belajar, dan karir atau jabatan. Kegiatan pendukung tampilan kepustakaan membantu peserta didik dalam memperkaya dan memperkuat diri berkenaan dengan permasalahan yang dialami dan dibahas bersama konselor pada khususnya, dan dalam pengembangan diri pada umumnya.

Pemanfaatan tampilan kepustakaan diarahkan oleh konselor dalam rangka pelaksanaan pelayanan dan atau peserta didik secara mandiri mengunjungi perpustakaan untuk mencari dan memanfaatkan sendiri bahan - bahan yang ada di perpustakaan sesuai dengan keperluan. Tampilan kepustakaan merupakan kondisi sangat memungkinkan peserta didik memperkuat dan memperkaya diri dengan atau tanpa bantuan konselor.

\section{F. Alih Tangan Kasus}

Alih tangan kasus, yaitu kegiatan pendukung bimbingan dan konseling untuk mendapatkan penanganan yang lebih tepat dan tuntas atas masalah ynag dialami peserta didik dengan memindahkan penanganan kasus dari satu pihak ke pihak lainnya. Kegiatan ini memerlukan kerja sama yang erat dan mantap antara berbagai pihak yang dapat memberikan bantuan atas penanganan masalah tersebut

Lembaga - lembaga alih tangan :

1. Rumah sakit, puskesmas, atau dokter praktek umum.

2. Lembaga pelayanan psikologis.

3. Lembaga kepolisian.

4. Lembaga - lembaga penyelenggara tes.

5. Lembaga penempatan tenaga.

Syarat - syarat pelayanan alih tangan kasus :

1. Alih tangan kasus harus disertai dengan data yang lengkap berkaitan dengan masalah yang dihadapi peserta didik bersangkutan.

2. Alih tangan kasus harus diberikan surat pengantar atau rekomendasi yang menjelaskan tujuan alih tangan kasus itu.

3. Alih tangan kasus harus disetujui oleh peserta didik yang bersangkutan.

4. Pelayanan alih tangan kasus itu harus tetap menjadi tanggungjawab sekolah.

5. Pihak yang dialihtangankan harus diminta untuk menyampaikan laporan terinci mengenai hasil upaya alih tangan itu kepada sekolah.

Langkah - langkah alih tangan kasus :

1. Alih tangan kasus dapat dimulai dengan inisiatif pihak tertentu yang menemukan peserta didik yang memiliki kesulitan dan tidak dapat dipecahkan oleh petugas itu sendiri.

2. Wali kelas ini memperkirakan kesulitan macam apa yang dihadapi siswa.

3. Wali kelas mengajukan alih tangan atau rujukan ini kepada kepala sekolah sebagai penanggungjawab puncak dalam program bimbingan dna konseling.

4. Kepala sekolah menunjuk terlebih dahulu diadakan pemeriksaan kesehatan fisik. 
5. Peserta didik beserta hasil pemeriksaan ditujukan kepada konselor.

6. Apabila konselor tidak dapat menangani sendiri, peserta didik dirujuk kepada ahli psikologi/psikolog untuk diperiks, apakah peserta didik tersebut memerlukan penanganan dalam suatu pembahasan kasus atau pelayanan testing dan dalam hal apa. 7. Apabila hasil pemeriksaan psikolog menunjukkan bahwa sebenarnya peserta didik tersebut tidak memerlukan pembahasan kasus dan tidak memerlukan layanan testing, maka psikolog tersebut memberikan rekomendasi tentang status siswa tersebut sebagai balikan kepada sekolah.

8. Apabila hasil pemeriksaan itu ternyata peserta didik tersebut tidak memerlukan pembahasan kasus, tetapi membutuhkan pelayanan testing, maka siswa tersebut dialih tangankan kepada lembaga penyelenggara tes untuk dilengkapi dengan data dari wawancara dengan orang tua dan pihak lain yang dibutuhkan. Berdasarkan hasil testing dan hasil wawancara itu disusunlah rekomendasi untuk dikembalikan kepada sekolah.

9. Apabila hasil pemeriksaan psikolog ternyata bahwa peserta didik itu memerlukan pembahasan yang lebih luas dengan berbagai pihak, maka diselenggarakan pembahasan kasus yang melibatkan berbagai pihak yang berkepentingan.

10. Dari hasil pembahasan kasus diberikan rekomendasi sesuai dengan status peserta didik tersebut.

\section{IV.KESIMPULAN}

Kegiatan pendukung bimbingan dan konseling terdiri dari enam buah, yaitu aplikasi instrument bimbingan dan konseling, himpunan data, kunjungan rumah, konferensi kasus, tampilan kepustakaan, dan alih tangan kasus. Dimana aplikasi instrument bimbingan dan konseling, himpunan data, dan kunjungan rumah berfungsi untuk pemahaman, konferensi kasus berfungsi untuk pemahaman dan pengentasan, tampilan kepustakaan berfumgsi untuk pemanfaatan dan penguatan, serta alih tangan kasus berfungsi untuk pengentasan.

\section{DAFTAR PUSTAKA}

Abin, Syamsuddin Makmum. 2003. Psikologi Pendidikan. Bandung : PT Rosda Karya Remaja.

Hallen. 2002. Bimbingan dan Konseling. Jakarta : Ciputat Press.

Prayitno, Amti Erman. 2004. Dasar - Dasar Bimbingan dan Konseling. Jakarta : PT

Rineka Cipta.

Prayitno, dkk. 2004. Pedoman Khusus Bimbingan dan Konseling. Jakarta : Depdiknas. Prayitno. 2012. Jenis Layanan dan Kegiatan Pendukung Bimbingan dan Konseling. Padang : FIP UNP 